\title{
ПРОБЛЕМА ДИСТРИБУТИВНОї СПРАВЕДЛИВОСТІ В КОНТЕКСТІ СУЧАСНИХ ТЕОРІЙ СУСПІЛЬНОГО ДОГОВОРУ
}

\section{Н.С. Литвиненко}

Метою класичних теорій суспільного договору, тобто теорій Гоббса, Локка, Руссо та Канта, є обгрунтування засад виникнення суспільства та держави, виходячи із суто раціональних міркувань. Фундаментальним для будь-якої з версій суспільного договору є питання легітимації прав власності та затвердження основних принципів розподілу матеріальних благ, яке відбувається, згідно контрактаріанській традиції, внаслідок укладення гіпотетичної угоди незалежними раціональними індивідами. В контексті сучасних теорій суспільного договору це питання набуває статусу проблеми дистрибутивної справедливості, сутність якої полягає в можливості надання релевантних підстав для керованого державою перерозподілу матеріальних ресурсів від більш успішних до менш забезпечених членів суспільства. Очевидно, загальний напрямок міркування стосовно цієї проблеми в межах контрактаріанської традиції передбачає надання таких підстав, які могли б бути погоджені раціональними індивідами в процесі укладення суспільного договору. Але розгляд проблеми в контексті теорії соціальної справедливості, де вона постає у вигляді питання «Шо є основою справедливого розподілу матеріальних ресурсів: структура самого розподілу чи певний процес, внаслідок якого цей розподіл виникає?», виявляє два протилежні підходи до її вирішення.

Структурна концепція дистрибутивної справедливості виправдовує справедливість матеріального розподілу, якщо він відбувається за заздалегідь визначеною схемою, функціонування якої гарантується дер-

Актуальні проблеми духовності 
жавою і, яка в будь-якому випадку має приблизно однаковий вигляд: «від кожного згідно його (здібностей, можливостей та ін.). . ; кожному згідно його (потреб, зусиль та ін.). .. ». Історична концепція визнає розподіл справедливим, якщо придбання матеріальних благ здійснюється не за конкретною схемою, а внаслідок певної легітимної процедури.

Серед представників першого підходу, що міркують в межах ліберальної традиції, найяскравішою фігурою є американський філософ Джон Ролз (1921-2002), відомий своєю книгою «Теорія справедливості» (1971), в якій він окрім інших розглядає проблему справедливого матеріального розподілу, пропонуючи власну структурну схему у вигляді двох принципів справедливості. Не менш значною в цьому контексті є теорія Рональда Дворкіна (нар. 1931), який, сприйнявши загальну мотивацію Ролза відносного його принципів, вважає, що інша, відмінна від Ролзової, дистрибутивна схема краще відповідатиме прийнятому лібералами ідеалу. Роберт Нозік (1938-2002), один з представників протилежної за поглядами лібертаріанської течії, на противагу Ролзу, вважає необхідним дослідити процес, внаслідок якого виникає розподіл, і знайти елементи, що зумовлюють його справедливість, у такий спосіб ставлячи під сумнів моральне право втручання будь-якої влади в процедуру розподілу матеріальних благ між членами суспільства.

На думку Альберта Уіла (Albert Weale), виникнення подібного диспуту між Ролзом та Нозіком зумовлене двозначністю у контрактаріанському розумінні суспільства як колективного підприємства індивідів, запровадженого заради їх спільної вигоди. Якщо наголос робиться на колективній природі суспільства, виникає ідея соціального союзу [9, с. 520-529], що передбачає необхідність запровадження певної структури матеріального розподілу. 3 іншого боку, наголошення на індивідyальній природі кожного учасника підприємства вимагає відповідного поважного ставлення до його особистих прав. Таким чином, вирішення згаданого диспуту являє собою пошук виправданого балансу між принципом індивідуальності особистості з одного боку та принципом соціального союзу з іншого [10, с.78].

Пошук шляхів встановлення рівноваги між двома принципами в межах існуючих підходів видається неможливим без урахування думки опонентів стосовно питання відчуження природних здібностей індивідів, реалізація яких може принести їм економічну користь. Чому вирішення цього питання $є$ фундаментальним при розгляді проблеми дистрибутивної справедливості та шляхів її розв'язання, стане зрозуміло в ході більш детального вивчення філософських теорій Ролза 
та Нозіка.

Центральна ідея ролзівської концепції справедливості полягає в твердженні, що всі соціальні первинні блага - свобода та можливості, прибуток та добробут, а також основи самоповаги - повинні розподілятися рівно, за виключенням ситуації, в умовах якої нерівний розподіл будь-якого або всіх цих благ відбувається на користь найменш забезпеченого члена суспільства [9, с. 303]. Таке формулювання основної ідеї, вочевидь, є надто загальним, тому Ролз впорядковує її основні елементи у вигляді двох принципів справедливості, зазначаючи, що реалізація першого принципу має пріоритет перед другим:

Перший принцип: кожна особа повинна мати рівне право на щонайширшу сукупну систему рівних основних свобод, яка була б сумісною з подібною системою свободи для всіх (принцип свободи).

Другий принцип: соціальні й економічні нерівності слід так упорядкувати, аби вони були:

а) на найбільшу користь для найменш привілейованих (принцип диференціації (різниці)),

б) а також прив'язані до посад та позицій, відкритих для всіх за умов чесної рівності можливостей (принцип рівності можливостей).

Перше правило пріоритету (пріоритет свободи): принципи справедливості мають бути класифіковані в лексичному порядку, а тому основні свободи можуть бути обмежені лише задля свободи.

Друге правило пріоритету (пріоритет справедливості над дієвістю й добробутом): другий принцип справедливості лексично передує принципові дієвості й засад максимізування суми вигод, а чесна можливість передує принципові різниці [3, с. 414-415].

Справедливість запропонованої Ролзом дистрибутивної схеми визначається фактом її одностайного прийняття в процесі укладення гіпотетичного суспільного договору. Саме аргумент суспільного договору, аргумент про те, яку політичну мораль було б раціонально обрати, якщо людям довелося б створювати суспільство, перебуваючи в умовах так званої «первісної позиції», Ролз вважає основним для своєї теорії. Зазвичай зображуваний як слабкий і непереконливий, в теорії Ролза механізм суспільного договору стає наріжним каменем аргументащії. Слабкість цього механізму виявляється в тому, що його основні елементи грунтуються на досить неправдоподібних засадах: в його 
класичному варіанті, умови суспільного договору вимагають від нас уявити такий стан дійсності (природний стан), в якому не існує жодної політичної влади; питання, яке потрібно вирішити індивідам, що знаходяться в такій ситуаціі, полягає в тому, який саме договір буде раціонально укласти для встановлення легітимної політичної системи, а також визначення її прав та обов'язків. Саме таке загальне формулювання має ідея суспільного договору, викладена в творах класиків XVII століття. Але як в своєму класичному варіанті, так і в сучасній інтерпретації вона наражається на одне й те саме критичне зауваження: ніколи не існувало такого природного стану, чи такого договору.

Проте Ролз інтерпретує суспільний договір насамперед не як угоду, дійсну або гіпотетичну, а як засіб виявлення імплікацій етичних засновків, що обгрунтовують моральну рівність індивідів. Він застосовує поняття природного стану не для того, щоб розробити історичні засади виникнення суспільства, або виправдати історичні зобов'язання політичної влади та індивідів; за допомогою механізму суспільного договору Ролз моделює ідею про моральну рівність людей.

Оригінальна концепція Ролза являє собою формальну модель суспільства раціональних взаємо незацікавлених (mutually disinterested) індивідів, яких він зображує в умовах так званої «торговельної гри» (bargaining game). Ролз робить спробу пристосувати цю торговельну гру до умов суспільного договору, тобто, представити групу індивідів, чия природа і мотиви були б такими, що зазвичай припускаються в теоріях суспільного договору, в ситуації торговельної гри, щоб за допомогою лише єдиного обмеження довести, на кшталт доведення теореми в теорії раціонального вибору, що єдиним рішенням для торговельної гри є моральний принцип, що характеризується конструктивністю, зв'язком 3 нашими стійкими моральними переконаннями та раціональністю, а також забезпечує незалежне місце для поняття права, одночасно визнаючи честь і гідність моральної особистості. За схемою ролзівської гри метою гравців $є$ досягнути одностайної згоди щодо низки принципів, які з моменту погодження і назавжди слугуватимуть критерієм оцінки інститутів або практик, в межах яких взаємодіють гравці. Кожен з гравців має рівне право пропонувати будьякі принципи, виходячи зі свого власного інтересу, але пам'ятаючи, що всі одностайно погоджені принципи стосуються всіх однаково і поширюють свою дію на майбутнє. Ролз наголошує на тому, що гравці визнають ці принципи до того, як починають вирішувати конкретні проблеми своєї життєдіяльності. Вимога, що запропонований принцип має поширюватися на майбутнє, а також умова, що обставини, в яких 
опиниться та чи інша особа в майбутньому не є відомими, на думку Ролза, гарантують, що визнані принципи будуть чесними. Саме тому Ролз називає свою концепцію «справедливість як чесність». Рішення, яке пропонує Ролз для цієї торговельної гри, - два вищезгадані принципи справедливості. Таким чином, умови зображеної Ролзом ситуації побудовані подібно до умов будь-якого прикладу теорії ігор (напр., «Дилема ув'язненого») і уможливлюють її успішне розв'язання за допомогою концепції раціональності притаманній теорії ігор.

Суть застосування механізму суспільного договору виявляється у прийнятті принципів справедливості в початковій ситуацї рівності, каркасом якої слугує модель «торговельної гри». В теорії Ролза ця ситуація дістає назву первісної позицї (the original position) і являє собою конструкцію, за допомогою якої він намагається визначити принципи, що, на його думку, мають регулювати «будь-яке добре організоване суспільство». Ролзівська первісна позиція «співпадає» $з$ природним станом у класичних теоріях суспільного договору [6, с. 61]. Вона не уявляється мов якийсь дійсний стан справ чи первісне становище культури, а розуміється як чисто гіпотетична ситуація, яка характеризується так, щоб виробити певну концепцію справедливості [3, с. 37]. На думку Ролза, первісна позиція є підхожим початковим статус-кво, який забезпечує справедливість-чесність досягнутих у ній домовленостей [3, с.44]. Мета її- надати спосіб ставлення до основних проблем соціального вибору, для яких не існує загально визнаного методу чіткого розв'язання. Це відбувається через спеціально сконструйовану ситуацію, що ставить проблему індивідуального вибору, яка може бути вирішена за допомогою інтуӥції, а також процедури прийняття рішень, що характеризується раціональною розважливістю. Ролз застосовує ідею первісної позиції, щоб описати таку справедливу процедуру, щоб принципи, погоджені за її допомогою, також були справедливими. Як основу для своєї теорії Ролз використовує поняття процедурної справедливості. Тому він вважає розумним поставити своїх раціональних осіб в однакові умови: позбавити їх в первісній позиції будь-яких привілеїв або недоліків, пов'язаних з природним таланом або соціальними обставинами. Ролз також припускає, що сторони не знають деяких конкретних фактів: свого соціального статусу, власного розуму й сили, а також своєї особистої концепції блага, деталей свого життєвого плану, особливих рис своєї психіки, конкретних обставин свого власного суспільства, свого покоління. Ролз полишає їх в первісній позиції лише зі знанням деяких загальних фактів: що їхнє суспільство підлягає обставинам справедливості; їм відомі політичні та економічні принципи, 
основи соціальної організації та людської психології, а також вони поділяють загальну концепцію блага, яка вимірюється в термінах дуже обмеженої низки первинних благ (primary goods): особиста та політична свобода, економічні та соціальні переваги та самоповага. На думку Ролза, обмеження, що накладаються на індивідів в первісній позиції мають бути такими, щоб завжди були обрані одні й ті самі принципи. У такий спосіб він доходить ситуації, яку називає завісою незнання, вважаючи її ключовою умовою для того, щоб інтерпретувати первісну позицію так, аби можна було в будь-який час прийняти її перспективу [3, с. 199]. За допомогою аналітичного інструменту завіси незнання Ролз має на меті виключити те, що він та інші моральні філософи вважають соціально несправедливим - випадкове обдаровування індивідів економічно корисними талантами. Ще одним важливим наслідком залучення до концепції інструменту завіси незнання $є$ те, що він неодмінно змушує гравців прийняти певну загальну концепцію блага, тобто концепцію первинних благ.

Ролз розрізняє «прозору» (thin) та «непрозору» (thick) концепції блага. «Прозора» концепція блага, яку використовують особи в первісній позиції, судячи щодо запропонованих принципів, означає, що сторони мають цілі (хоча вони не знають які саме), і що певні речі можуть бути використані для досягненні цих цілей. «Непрозора» ж концепція являє собою чиєсь конкретне бачення доброго життя в деталях, особисті ідеальні цілі. Отже в первісній позиції сторони не знають своїх цілей, але переконані в тому, що мають їх, а також розуміють, що первинні блага, відомі їм, на думку Ролза, певно стануть в пригоді задля досягнення їхніх цілей, якими б вони не були. Тому розглядаючи можливі принципи, особи ставлять собі за мету отримати якомога більшу частку цих основних вигод, яка може бути не більше ніж однаковою для всіх за умови рівності осіб в первісній позиції. Різні концепції блага, які можуть мати сторони, перешкоджають одностайності їхніх суджень та спричиняють конфлікт. Саме тому Ролз робить висновок про те, що, аби були погоджені якісь певні принципи, що потребує єдиного морального судження з боку сторін, необхідно виключити особисті концепції блага, тим самим забезпечивши одностайність в прийнятті будь-якого рішення. Власні концепції блага замінюються низкою основних благ, бажати які припускається раціональним, незалежно від того, що іще можна бажати взагалі. Використовуючи поняття первинних благ, Ролз намагається забезпечити те, що він називає Архімедовою позицією (Archimedean point), яка уможливлює чесний вибір поміж усіма більш-менш повними концепціями блага, що від- 
різняють людей одне від одного. Передбачається деяка теорія блага, яка, на думку Томаса Нагеля, є удавано нейтральною щодо різноманітних особистих концепцій і забезпечує менш загальний знаменник, на якому може базуватися чесний у відношенні до кожної сторони вибір. Модель первісної позиції Ролза містить в собі відчутний індивідуалістичний вплив, який надалі посилюється мотиваційним припущенням взаємної незацікавленості (mutual disinterest) та відсутності заздрості. Це припущення виключає розгляд тих концепцій блага, які залежать здебільшого від співвідношення між власним статусом і статусом інших (хоча Ролз дозволяє розгляд таких концепцій там, де вони мають вплив на самооцінку). Таким чином, первісна позиція передбачає не просто нейтральну теорію блага, але ліберальну індивідуалістичну концепцію, згідно якої найкраще, що можна бажати, це безперешкодне переслідування власних інтересів за умови, що воно не зачіпає прав інших [7, с. 9-10].

Саме така ситуація зображуваної Ролзом первісної позиції зумовлює одностайне погодження запропонованого ним принципу «мінімакс» (або «максимін» (the maximin principle)), який є частиною Другого принципу справедливості і уособлює структурну схему розподілу матеріальних благ між учасниками колективного підприємства $[9$, с. 62]. Ролз пропонує відмінний спосіб розподілу матеріальних благ, згідно якого добробут суспільства в цілому можливо максимізувати, тільки максимізуючи добробут найменш забезпечених його членів. Тобто, згідно Ролзу, жодна економічна діяльність не буде в змозі збільшити соціальний добробут, окрім того випадку, коли вона сприятиме покращанню становища найменш матеріально забезпеченого члена суспільства. Тому формуючи суспільство, яке дозволяє економічну та соціальну нерівність поміж його членами, раціонально буде надати становищу найменш забезпечених першорядне значення, адже, перебуваючи в первісній позиції, кожен з індивідів має рівні шанси опинитися саме в такому становищі, як тільки завісу незнання буде піднято.

Поряд з Ролзовою існують різні думки щодо того, що буде раціональним зробити в такій ситуації: ролзівська раціональна розважливість часто протиставляється раціоналізованому ризику. Якщо ми мали б хоч якесь уявлення про те, наскільки наші основні права будуть порушені в умовах, скажімо, утилітаристського суспільства, ми мали б змогу краще усвідомити раціональність ризикованого вибору в первісній позиції. Схильність до ризику, так само як обачливість, риса притаманна далеко не кожній особі, тому здійснення ризикованого кроку завжди є рішенням особистим і залежить від індивідуальних 
властивостей характеру тої чи іншої людини. Але Ролзова завіса незнання виключає як інформацію про конкретні обставини майбутнього суспільства, так і про особливі риси власної психіки. Саме тому в даному випадку єдиним раціональним рішенням видається прийняття стратегії «мінімакс»- максимізування матеріальних ресурсів за умов можливого заміщення мінімальної, тобто найгіршої, посади.

Багато філософів критикують ролзівське твердження про раціональність «мінімаксу», вказуючи на те, що так само раціональним, якщо навіть не більш раціональним, є ризикування в умовах утилітаризму. Інші стверджують, що неможливо оцінити раціональність ризику, якщо невідомими є конкретні деталі суспільства або власна схильність до ризику, таким чином звинувачуючи Ролза в тому, що він спеціально винайшов інструмент завіси незнання, аби раціоналізувати свій принцип диференціації як єдино можливий в умовах первісної позиції $[6$, c. 67].

Разом із застосуванням завіси незнання виключається не тільки інформація про особливості власного суспільства, власного соціального стану, не тільки запроваджується спільна концепція первинних благ, що зумовлює одностайність вибору, виключається також будь-яке знання про власні природні таланти та здібності. Коли ми розмірковуємо про суспільство з тою мірою неупередженості, якої вимагає чесність, воно постає як колективне підприємство і вимагає прийняття принципу диференціації в якості угоди, про розгляд природних здібностей як спільного надбання і рівний розподіл результатів їх використання. 3 усуненням завіси незнання кожен виявиться в різній мірі обдарованим різними здібностями. Таким чином, більш талановиті матимуть змогу, доклавши певних зусиль, отримати більший прибуток, ніж ті, хто, скажімо, виявиться скаліченим фізично або розумово, чи просто матиме нижчий рівень IQ. Логічно припустити, що з початку займаючи рівне матеріальне становище, деякі (більш талановиті та працелюбні) особи згодом набудуть певних економічних привілеїв завдяки виключно своїм природним здібностям. Ролзівський принцип «мінімакс» дозволить таку економічну нерівність тільки за умови, що найменш забезпечені також покращать своє становище порівняно з ситуацією економічної рівності. Таким чином, розгляд природних здібностей як спільного надбання передбачає, що більш талановиті повинні будуть працювати не лише задля власної користі, а також, і насамперед, задля користі тих, хто має найгірше матеріальне становище. Частина прибутку, отриманого більш талановитими буде перерозподілена поміж менш успішними членами суспільства. Саме так має працювати ролзівська схема 
дистрибутивної справедливості.

Основні засновки викладеного Ролзом аргументу видаються цілком вірогідними, але зроблені ним висновки залишають деякі сумніви. 3 припущення, що соціальні та природні переваги є довільними, випливає той факт, що тільки у випадку, коли економічна нерівність пов'язана з користуванням саме цими перевагами, вона має впливати на матеріальний розподіл у суспільстві на користь найменш забезпеченої особи. Але ролзівський принцип диференціації стверджує, що усіляка економічна нерівність, що так чи інак має місце в суспільстві, має бути упорядкована на найбільшу користь найменш привілейованого. Уявімо ситуацію, коли людина не народилася в сім'ї, що має соціальні привілеї, і не є обдарованою жодними особливими здібностями, але завдяки власному вибору і докладеним зусиллям їй вдалося отримати більший матеріальний прибуток порівняно з іншими. Ролзівський дистрибутивний принцип вимагатиме від такої людини витратити частину свого прибутку на покращення становища інших, не пояснюючи при цьому, чому принцип диференціації діє в усіх випадках нерівного економічного становища, а не обмежується виключно випадками економічної нерівності, пов'язаної з морально довільними факторами [6, с.58]. Ролз, вочевидь, не надає значення факту, що становище людини в суспільстві зумовлене не тільки соціальними та природними обставинами, в рівній мірі воно залежить і від особистого вибору скористатися цими обставинами, докласти певних зусиль для збільшення власних матеріальних ресурсів. Тому наявність виключних здібностей не забезпечує автоматично виключного матеріального становища в суспільстві, і дві більш-менш однаково соціально і природно обдаровані людини не обов'язково досягнуть однакового економічного рівня. Коли нерівність прибутків є результатом вибору, а не обставин, принцип диференціації породжує, радше ніж усуває несправедливість. Як це художньо описав Дадлі Ноулз (Dudley Knowles): «кожен добре пригощається на Ролзовому святі, але деякі не мають права там знаходитися. В особливості ... ледачі, жебраки, а також ті, що ухиляються від роботи, не повинні сидіти за столом» [5, с. 234].

Спробу врівноважити особистий вибір та особисті обставини, спираючись на фундаментальні ідеї лібералізму про свободу та рівність, робить інший американський філософ Рональд Дворкін. Його проект в цілому подібний до первісної позиції Ролза, де особи знаходяться за дещо модифікованою завісою незнання: їм не відома їхня частка в розподілі природних здібностей, тому всі вони уявляються однаково вразливими до природних недоліків. В початковій ситуації рівності 
кожній особі надається однакова кількість матеріальних ресурсів, певну частину з яких вона може за бажанням витратити на страхування від можливого фізичного чи розумового каліцтва, або будь-яких інших природних негараздів, отриманих при народженні. Соціальні блага суспільства в повному обсязі «продаються» на так званому аукціоні, де кожен може придбати такий їх набір, який він тільки може собі уявити, і в такому розмірі, який дозволить йому отримати кількість матеріальних ресурсів, що залишилася після витрат на страхування від природних недоліків. У такий спосіб, Дворкін намагається віднайти рівновагу між особистим вибором, який проявляється в можливості придбати за власним бажанням будь-який набір соціальних благ і не вимагає прийняття спільної концепції ролзівських первинних благ, та довільним обдаруванням природними здібностями та недоліками. Особа має змогу витратити будь-яку частину своїх початкових ресурсів на страхування, а залишок віддати за певний набір соціальних благ. Таке припущення, згідно Дворкіну, є раціональним, тому що кожен забажає в більшій чи меншій мірі вберегтися від природних недоліків, але не витратить на страхування всіх своїх ресурсів, усвідомлюючи необхідність придбання певної частки соціальних благ. Таким чином, маючи джерелом ресурси, які перед початком аукціону гіпотетично погодилися сплатити особи в фонд страхування, прибутковий податок являв би собою спосіб, у який у вигляді медичного обслуговування та інших заходів в тій чи іншій мірі могли б бути компенсовані природні недоліки для менш обдарованих.

Дворкін визнає, що його концепція, хоча і представляє поліпшений варіант ролзівської дистрибутивної схеми, не усуває проблему повністю, тому викладений ним аргумент завжди залишатиметься теорією «другого гатунку» [6, с.83-84]. Та все ж Дворкін переконливо стверджує, що справедливий розподіл повинен визначити, які саме аспекти економічного становища людини є наслідком їі власного вибору, а які випливають $з$ переваг та недоліків пов'язаних з її природними обставинами. В цьому і полягає важливість його концепції, яка визначає дистрибутивну схему, що поважає моральну рівність осіб, компенсуючи нерівні обставини, і разом з тим визнає індивідів відповідальними за наслідки своїх дій. Однак гіпотетичні підрахунки, що їх вимагає теорія, виявляються такими складними, а їх імплементація - такою важкою, що теоретичні переваги теорії неможливо застосувати на практиці. Теорія Дворкіна є спробою розв'язати проблему ролзівської концепції дистрибутивної справедливості, являючи собою намагання радше поліпшити, ніж відхилити їі основні припущення. 
На противагу Дворкіну, Роберт Нозік критикує основні положення ролзівської теорії, виявляючи протиріччя між запропонованими Ролзом двома принципами справедливості. Вказуючи на пріоритет першого ролзівського принципу перед другим, Нозік стверджує, що свобода індивідів руйнує будь-яку керовану державою схему перерозподілу матеріальних благ від більш забезпечених до менш забезпечених членів суспільства. В якості ілюстрації свого твердження Нозік наводить «приклад Уілта Чемберлена», суть якого полягає в наступному. Уявімо, що гравець Вищої баскетбольної ліги Уілт Чемберлен володіє виключними для його професії здібностями, тому усі баскетбольні клуби мріють укласти з ним контракт на наступний сезон. Усвідомлюючи переваги власного становища, Уілт позначає одним з пунктів свого контракту, що 25 центів з кожного проданого квитка надходитимуть на його особистий рахунок додатково до його стабільної зарплатні. Баскетбольні вболівальники обожнюють дивитися, як грає Уілт, тому на вході до стадіону радо опускають додаткові 25 центів у спеціальну скриньку з написом «Уілт Чемберлен». Припустимо, що за сезон ігри за участю Уілта відвідало 100000000 осіб, що принесло йому додаткових $250000 \$$, що складає набагато більше ніж середній прибуток. Чи має він право користуватися цими грошима? [8, с. 160-162] Нозік міркує так, що, якщо початковий розподіл матеріальних ресурсів (наприклад, це був рівний розподіл між усіма членами суспільства) $є$ прийнятним i визнається справедливим, а подальший перерозподіл на користь Уілта Чемберлена з'являється внаслідок вільно прийнятого рішення витратити 25 центів в обмін на змогу побачити гру за участю Уілта, то хіба цей другий розподіл матеріальних ресурсів не має також визнаватися справедливим? Якщо особи мають право розпоряджатися своїми матеріальними ресурсами, набуте ними в умовах початкового розподілу, чи не означає це, що вони також мають право віддати їх певну частку Уілту Чемберлену за власним бажанням? Після передачі цієї частки Уілту третя сторона (тобто ті, хто не купував квитка на гру) так само має право на свою частину матеріальних ресурсів, яка $€$ незмінною, незалежно від того, грає Уілт чи ні. В зв'язку з цим Нозік порушуе питання про те, яким чином може така передача від однієї особи до іншої стати приводом для висунення вимог стосовно частки від переданої суми з боку третьої сторони (тобто держави), яка до передачі не мала прав на власність жодної зі сторін [8, с. 160-162]. На думку Нозіка, перерозподіл на користь Уілта Чемберлена виникає внаслідок вільної передачі частини матеріальних ресурсів від одної сторони до іншої, а втручання у вигляді збору податків в цей процес держави, яка 
$є$ третьою стороною, відбувається за рахунок значних обмежень індивідуальної свободи, тому накладання податків Нозік, за його власним висловом, прирівнює до примусової праці [8, с. 169].

Спираючись на принцип придбання власності, сформульований Локком, Нозік будує власну дистрибутивну схему у вигляді трьох основних тверджень:

1. принцип передачі - будь-що, що придбано справедливо, може бути справедливо передано;

2. принцип справедливого початкового придбання - аргумент про те, як люди від початку заволоділи тим, що може бути передано згідно з першим принципом;

3. принцип виправлення несправедливості - аргумент про те, як поводитися з власністю, якщо вона була придбана або передана несправедливо [8, с. 160].

Спираючись на локківський принцип, що визначає власність як результат сполучення предмета з особистою працею [2, с. 277], Нозік визнає природні здібності індивідуальним надбанням, виходячи з твердження про те, що людина в початковій ситуації рівності володіє власною особистістю. Таким чином, згідно Нозіку, перерозподіл матеріальних ресурсів на користь Уілта Чемберлена є цілком легітимним, адже з'являється як наслідок реалізації Уілтом особистих природних здібностей, які становлять предмет його індивідуальної власності.

У такий спосіб Нозік доходить висновку про те, що єдино виправданою є так звана «мінімальна держава», функції якої обмежуються захистом громадян від іноземного втручання, пограбувань, шахрайства і т.ін. Будь-яка більш екстенсивна влада буде порушувати право осіб проти примусу робити певні речі і визнається невиправданою [8, c.ix].

Отже, твердження про те, що визнання індивідів рівними вимагає обмежень щодо використання однієї особи задля добробуту інших, чи суспільства взагалі, безперечно, єднає ліберальну та лібертаріанську теорії, представлені Ролзом та Нозіком. Обидва визнають, що індивіди мають права, які повинно поважати справедливе суспільство. Однак, обидва різняться при відповіді на питання про те, які саме права є найважливішими в умовах справедливого суспільства. Підсумовуючи, можна сказати, що для Ролза одним з найважливіших прав є право на певну частину матеріальних ресурсів суспільства; для Нозіка ж таким 
є право на власну особистість (самовласність (self-ownership)). Згідно його думки, Ролзова вимога, що ресурси, вироблені більш талановитими, мають бути використані для покращання добробуту найменш забезпечених, $є$ несумісною з визнанням самовласності, яка передбачає володіння особистими здібностями і відповідно всім тим, що створене шляхом реалізації цих здібностей. Але проблема полягає не в тому, що Ролз і Дворкін вважають, що одні можуть володіти особистістю і здібностями інших, на кшталт рабовласності. Навпаки, зображувана ними гіпотетична позиція рівності застосовується для обгрунтування аргументу, що жодна особа не $є$ власністю іншої. Ліберали визнають за кожною особою легітимне володіння її здібностями разом з правом використовувати їх згідно вільного вибору. Однак, зазначаючи, що обдарування здібностями є випадковим, ліберали також визнають, що право на володіння власними здібностями не передбачає нерівний розподіл матеріальних благ, що $є$ наслідком реалізації цих здібностей. Згідно ліберальним теоріям, природно обділені люди мають законне право висувати відповідні вимоги до природно обдарованих, а обдаровані мають моральний обов'язок по відношенню до тих, чиї природні обставини виявилися при народженні менш сприятливими. Тому дистрибутивна схема, запропонована Дворкіним передбачає наявність страхового фонду в якості компенсації для природно обділених, а Ролзова теорія справедливості дозволяє обдарованим користуватися результатами реалізації своїх здібностей тільки за умов відповідного поліпшення матеріального становища найменш забезпечених. Проте жодна з розглянутих нами теорій не здатна забезпечити відповідний баланс між принципами індивідуальної особистості та соціального союзу, віддаючи перевагу колективному перед індивідуальним (Ролз, Дворкін), або навпаки (Нозік).

Спробу захистити принцип індивідуальності особистості, виходячи з ролзівських засад про справедливість керованого державою матеріального розподілу, робить інший політичний філософ, якого, зважаючи на викладені ним міркування, неможливо віднести ні до прибічників Ролза, ні до його ідейних опонентів - представників лібертаріанської течії. Девід Готьє (David Gauthier) (нар. 1932) представляє радикальну версію суспільного договору, яку характеризують риси подібні до ситуації природного стану, зображуваної Гоббсом, а також до принципу придбання власності, сформульованого Локком, який Готье інтерпретує в дусі ідей Нозіка [4, с. 159].

Концепції лібералізму і лібертаріанізму, а також теорії взаємної користі, прикладом якої виступає теорія Готьє, застосовують механізм 
суспільного договору в якості невід'ємного компонента своєї аргументації. Однак, якщо в Ролза його застосування пов'язане з «нашим природним чуттям справедливості», тобто імпліцитно обгрунтовує твердження про те, що люди становлять цінність з моральної точки зору, а не тому що можуть сприяти або зашкодити іншим [9, с. 179-180], Готьє вважає, що не існує моральних зобов'язань, так само як і моральної рівності осіб, що передує їх природній фізичній нерівності, використовуючи ідею суспільного договору в якості угоди, що укладається задля взаємної користі індивідів і надає штучної моральної цінності тим чи іншим діям, які не мають внутрішнього морального статусу. Так само протистоїть теорії Готье концепція Нозіка: взаємна користь підпорядковує індивідуальну самовласність владі інших, в той час як Нозік визнає самовласність природним правом особистості. Згідно Нозіку, примушувати інших несправедливо не тому, що це невигідно для того, хто примушує, а тому, що людина розглядається ним як ціль, а її силування принижує її внутрішній моральний статус, таким чином уособлюючи ставлення до неї як до засобу. Отже, Нозік грунтує свою концепцію на твердженні про внутрішній моральний статус людини, яке цілком заперечує теорія Готье.

В книзі «Мораль за згодою» ('Morals by Agreement') (1986) Готьє намагається захистити концепцію, яка надає незалежний статус принципу індивідуальної особистості, збалансовано поєднаному з принципом соціального союзу. Метою Готье є надання необхідного обгрунтування праву використовувати особисті фізичні та розумові здібності задля власної користі за умови, що при цьому не буде завдано шкоди становищу інших. На відміну від Ролза, Готьє не використовує інструмент завіси незнання в описаній ним початковій ситуації: сторони укладають між собою угоду, володіючи повною інформацією стосовно себе та обставин свого існування. Готьє порівнює свою «вихідну позицію» (the initial position) з самотнім існуванням Робінзона Крузо на безлюдному острові, описуючи її як вільну, оптимальну та позбавлену впливу зовнішніх факторів. Разом з характеристикою про відсутність в ній будь-яких засад внутрішнього морального статусу, зображувана Готьє початкова ситуація уявляється ним як «вільна від моралі зона» ('morally free zone'). Завданням своєї теорії Готьє бачить визначення тієї угоди, яку буде раціонально укласти в подібних обставинах, з метою іiї подальшого використання для отримання нормативних принципів соціального і політичного вибору. Ця загальна проблематика розробляється відносно права використовувати особисті таланти та здібності, яке, на думку Уіла, становить центр моральних засад принципу 
індивідуальності особистості [10, с. 85].

Грунтуючи свій доказ на раціональності соціального союзу, Готье пропонує власний принцип «відносного мінімаксу» (дещо пом'якшений ролзівський принцип «мінімакс»), який стверджує, що кожна особа має право знати, володіти, використовувати та мати вигоду з власних здібностей, якщо умови існуючої економічної ситуації виявляються для цього сприятливими, при цьому не використовуючи здібності інших, що, можливо, не покращить їх становища, але і не сприятиме його погіршенню $[4$, с. 274]. Важливою рисою аргументу є те, що природні здібності не розглядаються Готьє як ті, що мають якусь внутрішню цінність, навпаки, успішна їх реалізація залежить від економічної ситуації, що склалася, і передбачає взаємодію з іншими. Самі по собі будь-які виключні здібності нічого не варті і не вважаються гарантовано корисними в будь-якій ситуації. Якщо Уілт Чемберлен опинився би в суспільстві, де й не чули про баскетбол, навряд чи він відіграв би більш-менш значну роль в існуючому матеріальному розподілі.

На думку Готьє, розподіл матеріальних благ згідно схеми принципу відносного мінімаксу становить єдиний раціоналізований базис матеріального розподілу, а твердження про раціональність соціальної співпраці, на противагу моральному припущенню про пріоритет соціального союзу перед особистістю, зумовлює одностайне прийняття гіпотетичного договору раціональними індивідами. У такий спосіб Готьє намагається захистити індивідуальну свободу членів суспільства в умовах матеріального розподілу, здійснюваного державою.

Розглянувши в такий спосіб сучасні теорії суспільного договору, в межах яких здійснюється пошук шляхів розв'язання проблеми дистрибутивної справедливості, можна зауважити, що, незважаючи на велику кількість відмінних, а інколи і цілком протилежних рис, все ж таки видається можливим встановити спільні елементи, що складають фундамент будь-якої з досліджених концепцій. Беззаперечну першість серед них має механізм суспільного договору, який в кожній концепції застосовується з різною метою, зберігаючи при цьому більш-менш незмінну систему компонентів, таких як початкова ситуація, сторони, які, знаходячись в її умовах, одностайно укладають певну гіпотетичну угоду, а також принципи, регулюючі життєдіяльність сторін, що виникають як її наслідок. Другий фундаментальний елемент, який беруть на озброєння всі згадані автори, становить інструментальна концепція раціональності подібна до тої, що використовується в теорії ігор. Однак, поєднавши згадану концепцію з питанням про відчуження економічно вигідних здібностей індивідів в тому ракурсі, який надає його 
вирішенню наголос на тому, що можливість реалізації цих здібностей залежить не від їх наявності, а від сприятливої економічної ситуації, що складається в існуючому суспільстві, Готьє формулює проблему, яку неможливо вирішити, виходячи з концепції раціональності теорії ігор. Хоча збереження суспільних практик вимагає загального, якщо не універсального, дотримання певних соціальних норм, у великій економічній системі жоден індивід сам по собі, чи будь-яка незначна група індивідів не $\epsilon$ потрібною для її функціонування. Таким чином, жоден індивід не має торговельної сили, тобто не має змоги пропонувати свою підлеглість системі в обмін на частку в розподілі її матеріальних ресурсів. Коли прибутки такої системи визнаються відносно високими, індивіди, що не приймають участь в їх розподілі, виборюють право опинитися в межах її дистрибутивної схеми, а не «торгуються» за більшу частку, щоб бути змушеними прийняти реалізований системою дистрибутивний принцип. В такому випадку подібні норми та суспільні практики більше не становлять продукт суми скооперованих дій індивідів, натомість вони мають цілком об'єктивне існування, що вимагає індивідуального підкорення. За таких умов єдиною концепцією раціональності здатною спонукати індивідів до підкорення видається не та, що базується на практичній користі для індивідів, отримуваній від цього підкорення, а саме та концепція, що, навпаки, закликає до раціональності бути спроможним бажати тільки те, що могло б бути раціонально бажаним усіма $[10$, с. 93$]$. Питання про те, чи виходить вирішення окресленої проблеми за межі теорій суспільного договору, чи передбачає застосування іншої концепції раціональності, залишається відкритим, але напевно можна сказати, що межі контрактаріанізму залишають достатньо місця для більш ніж однієї концепції раціональності.

\section{1 Бібліографія}

[1] Алексеева T.А. Джон Роулз и его теория справедливости // Вопросы философии. - 1994. - № 10.

[2] Локк Дж. Два трактата о правлении. Соч. в 3 т. /Пер. с англ. и лат. Т. 3 /Ред. и сост., авт. примеч. Субботин А.А. - М.: Мысль, 1988.

[3] Ролз Дж. Теорія справедливості. Пер. $з$ англ. О. Мокровольський. - К.: Основи, 2001. 
[4] Gauthier D. Morals by Agreement. - Oxford: Clarendon Press, 1986.

[5] Knowles D. Political Philosophy. - London: Routledge, 2001.

[6] Kymlicka W. Contemporary Political Philosophy.-Oxford: Clarendon Press, 1995.

[7] Nagel T. Rawls on Justice // Reading Rawls. Edited by Norman Daniels. - Stanford University Press, 2003.

[8] Nozick R. Anarchy, State and Utopia.-Basic Books, 1974.

[9] Rawls J. A Theory of Justice. - Cambridge, MA: Harvard University Press, 1971.

[10] Weale A. Justice, Social Union and the Separateness of Persons. Rationality, Justice and the Social Contract. - Ann Arbor: The University of Michigan Press, 1993.

[11] Wolff J. An Introduction to Political Philosophy. - Oxford University Press, 1996.

[12] Wolff R.P. Understanding Rawls. - Gloucester, Mass: Peter Smith, 1990. 